\title{
A validation of the Postpartum Specific Anxiety Scale 12-item research short-form for use during global crises with five translations
}

Sergio A. Silverio ${ }^{1,2,3^{*}}$, Siân M. Davies ${ }^{2,4,5}$, Paul Christiansen², Marta E. Aparicio-García ${ }^{6}$, Alessandra Bramante , Ping Chen ${ }^{8}$, Natalia Costas-Ramón ${ }^{6}$, Carolina de Weerth ${ }^{9}$, Anna M. Della Vedova ${ }^{10}$, Lilliam Infante Gil ${ }^{11}$, Hellen Lustermans ${ }^{9}$, Jaqueline Wendland ${ }^{11}$, Jihong $\mathrm{Xu}^{12}$, Jason C. G. Halford ${ }^{2,13}$, Joanne A. Harrold ${ }^{2}$ and Victoria Fallon ${ }^{2}$

\begin{abstract}
Background: Global crises inevitably increase levels of anxiety in postpartum populations. Effective and efficient measurement is therefore essential. This study aimed to create a 12-item research short form of the 51-item Postpartum Specific Anxiety Scale [PSAS] and validate it for use in rapid response research at a time of global crises [PSAS-RSF-C]. We also present the same 12-items, in five other languages (Italian, French, Chinese, Spanish, Dutch) to increase global accessibility of a psychometric tool to assess maternal mental health.

Methods: Twelve items from the PSAS were selected on the basis of a review of their factor loadings. An on-line sample of UK mothers $(N=710)$ of infants up to 12 weeks old completed the PSAS-RSF-C during COVID-19 'lockdown'.

Results: Principal component analyses on a randomly split sample $(n=344)$ revealed four factors, identical in nature to the original PSAS, which in combination explained $75 \%$ of the total variance. Confirmatory factor analyses $(n=366)$ demonstrated the four-factor model fit the data well. Reliability of the overall scale and of the underlying factors in both samples proved excellent.

Conclusions: Findings suggest the PSAS-RSF-C may prove useful as a clinical screening tool and is the first postpartum-specific psychometric scale to be validated during the COVID-19 pandemic. This offers psychometrically sound assessment of postpartum anxiety. By increasing the accessibility of the PSAS, we aim to enable researchers the opportunity to measure maternal anxiety, rapidly, at times of global crisis.
\end{abstract}

Keywords: Anxiety, Maternal mental health, Psychometric assessment, Postpartum

\footnotetext{
* Correspondence: Sergio.Silverio@kcl.ac.uk

'Department of Women \& Children's Health, School of Life Course Sciences, King's College London, London, UK

${ }^{2}$ Department of Psychology, Institute of Population Health, University of Liverpool, Liverpool, UK

Full list of author information is available at the end of the article
}

(C) The Author(s). 2021 Open Access This article is licensed under a Creative Commons Attribution 4.0 International License, which permits use, sharing, adaptation, distribution and reproduction in any medium or format, as long as you give appropriate credit to the original author(s) and the source, provide a link to the Creative Commons licence, and indicate if changes were made. The images or other third party material in this article are included in the article's Creative Commons licence, unless indicated otherwise in a credit line to the material. If material is not included in the article's Creative Commons licence and your intended use is not permitted by statutory regulation or exceeds the permitted use, you will need to obtain permission directly from the copyright holder. To view a copy of this licence, visit http://creativecommons.org/licenses/by/4.0/ The Creative Commons Public Domain Dedication waiver (http://creativecommons.org/publicdomain/zero/1.0/) applies to the data made available in this article, unless otherwise stated in a credit line to the data. 


\section{Background}

\section{The COVID-19 global pandemic context}

The Coronavirus [SARS-CoV-2] or COVID-19 pandemic poses a devastating risk to the health of the global population. Amongst those thought to be most vulnerable are pregnant women and newborn infants, although guidance rapidly changed to state that pregnant women are no more vulnerable than the general population [1]. Although the growing body of evidence remains conflicting about the size of the risk to these populations, perinatal deaths have been reported [2]. This makes the perinatal period a time of increased vulnerability [3]. Whilst COVID-19 poses a serious physical health risk to those who contract the virus, there is evidence for it also affecting mental health outcomes [4, 5]. Poor mental health in relation to COVID-19 has been associated with various Government mandated restrictions, which have been enforced in an attempt to slow the spread of the virus. These include 'quarantine' (the enforced isolation of persons with or suspected of having the virus) [6]; 'social distancing' (the physical separation of persons outside of those in one's family) [7]; 'lockdown' (the closure of public venues and banning of non-essential travel) [8]; and 'shielding' (where the most vulnerable including pregnant women - are advised to remain at home and leave under no circumstances) [1]. Given the expected effect of the COVID-19 pandemic on mental health coupled with pregnant women and newborn infants being labelled as vulnerable groups [1], it is important to assess and understand the mental health effects in perinatal women [9]. During normal circumstances, approximately $20 \%$ of all women who give birth are thought to experience mental health problems [10]. The global pandemic is set to pose "unprecedented challenges that can significantly impact on women's mental health" during the perinatal period [3], hence potentially driving these numbers even higher.

\section{Postpartum anxiety}

In 2014, the National Institute of Health and Care Excellence [NICE] requested attention to the underdetection of postpartum anxiety in recognition of the significant burden it poses [11]. Postpartum anxiety is associated with many negative maternal and infant outcomes including reduced breastfeeding [12], reduced maternal sensitivity [13], impaired bonding [14], difficult infant temperament [15], atypical neurodevelopment [16], and child emotional and behavioural problems [17]. However, general measures of anxiety are relied upon in a large majority of studies examining postpartum anxiety, but are psychometrically problematic $[11,18]$.

The Postpartum Specific Anxiety Scale [PSAS] examines the frequency of maternal and infant focused anxieties experienced by women across the first year of their infants' life [19]. The 51-item measure assesses four domains of anxiety, specific to the postpartum period. Factor 1 (Maternal Competence and Attachment Anxieties) contains 15 -items which address anxieties relating to maternal self-efficacy, parenting competence, and the mother-infant relationship. Factor 2 (Infant Safety and Welfare Anxieties) has 11-items which relate to fears about infant illnesses, accidents, and cot death. Factor 3 (Practical Infant Care Anxieties) includes 7-items covering anxieties which are specific to infant care such as feeding, sleeping, and general routine. Finally, Factor 4 (Psychosocial Adjustment to Motherhood) contains 18items which address adjustment concerns since the birth of the baby about management of personal appearance, relationships and support, work and finances, and sleep. Each answer is given a score of between 1 and 4 with the maximum score being a total of 204. Initial validation of the English-language version demonstrated a score of 112 or above may be indicative of a clinical level of anxiety [19].

The predictive validity of the measure has been examined and confirmed in relation to infant feeding outcomes and behaviours [20], and maternal bonding behaviours [21]. Across both of these studies, the PSAS demonstrated stronger predictive power than a general non-childbearing measure of anxiety.

To date, initial validity and reliability has been demonstrated in one large UK sample [19], and more recently two Turkish samples [22, 23]. The English-language PSAS is currently being used throughout the UK, Canada, Australia, Ireland, Rwanda, and the USA. Translation of the PSAS has taken place in Italy, France, China, Spain, and The Netherlands, but are, as yet, unpublished. Further translations are currently ongoing in Brazil, Egypt, Germany, Greece, India, Indonesia, Iran, Iraq, Jordan, Malaysia, Portugal, and The Philippines. A further translation into Burmese (the language of Myanmar) is being undertaken by a research team in Thailand. (See Fig. 1).

\section{Study rationale}

Research to understand the psychological impact of COVID19 in perinatal populations is critical in mitigating the severity of the outbreak. Rapid progress in addressing this pandemic depends upon a coherent and integrated response from researchers [24]. There have also been global calls for the mental health sciences to work in a multi-disciplinary fashion to address the possible mental health crisis which may follow the physical health pandemic [25], and where possible make addressing mental health needs an integral part of the COVID-19 response [26]. The 51-items in the PSAS take approximately $10 \mathrm{~min}$ for mothers to complete which, when integrated into a survey containing a battery of psychometric scales, may be burdensome, especially during 


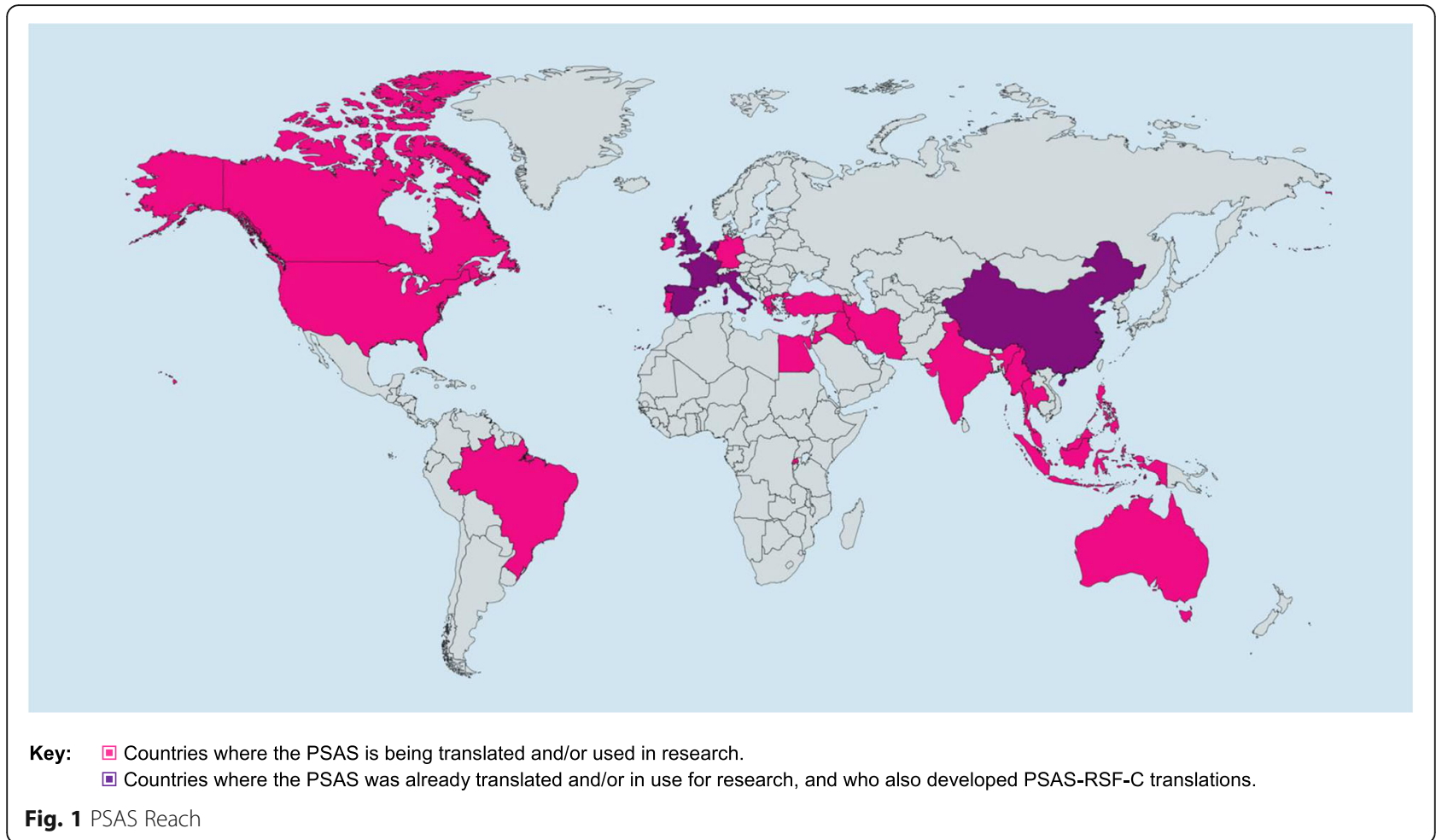

the current pandemic, where specific populations may be over-sampled. Therefore, during times of crises such as the current COVID-19 global pandemic, it is desirable to use shortened measures, to reduce participant burden. Furthermore, to the authors' knowledge, there have been no psychometric scales (including measures of perinatal mental health) validated for use during the current pandemic.

In the UK, NICE guidelines recommend psychometric measures should contain fewer than 12 items for optimal accessibility [11]. This article reports the development of a 12-item research short-form of the PSAS, validated for use in global crises [PSAS-RSF-C]. The validation of the PSAS-RSF-C, in English, acts as a nested psychometric study within a larger on-line UK survey: PRegnancy and Motherhood during COVID-19 [The PRaM Study]. As the 51-item PSAS is currently undergoing multiple translations (all at various stages of validation), we also present, within this paper, the same 12 items, in five other languages (Italian, French, Chinese, Spanish, and Dutch). By increasing the accessibility of the PSAS, validated for use during COVID-19, we aim to enable researchers the opportunity to measure maternal anxiety, rapidly and accurately, at times of global crisis.

\section{Methods}

\section{Participants}

A UK sample of mothers $(N=710)$ with infants aged between birth and 12 weeks were recruited to complete an on-line survey. All data were collected from participants during the period of time in which the UK Government implemented the initial form of social 'lockdown' (23 March 2020-10 May 2020).

Maternal- and infant-related demographic questions were asked at the beginning of the survey (Table 1). Specific questions were also asked on the incidence of COVID-19 in the mother and any family members. Maternal age ranged between 18 and 46 years $(M=31.69, S D=5.15)$ and infant age ranged between birth and 12 weeks $(\mathrm{M}=7.92, \mathrm{SD}=$ 3.67). Women were predominantly white (95\%), married (57\%), university educated (64\%), and professionals (52\%). In addition, 140 women had a clinical diagnosis of anxiety (20\%); 85 had a clinical diagnosis of depression (12\%); and 28 had a clinical diagnosis of PTSD (4\%). Forty-nine women believed they had COVID-19 (7\%), with two of these women having been tested. Additionally, 125 women believed a family member had COVID-19 (18\%), with ten of these women reporting their family member had been tested. Finally, 242 women believed their birth experience had been affected by UK Government 'lockdown' restrictions (34\%).

\section{Design and procedure}

Participants were recruited through on-line social media platforms via an advertisement providing a link to the Qualtrics survey platform. Prior to the main survey, an electronic information sheet and consent form were provided with a tick box to confirm consent. Upon 
Table 1 Maternal, Infant, and COVID-19 Characteristics ( $N=710$ Mothers)

\begin{tabular}{|c|c|c|c|c|c|}
\hline Maternal age (mean years $\pm S D$ ) & $\begin{array}{l}31.69 \\
(5.15)\end{array}$ & Maternal Diagnoses & $\begin{array}{l}\text { Value } \mathrm{n} \\
\text { (\%) }\end{array}$ & & \\
\hline \multirow[t]{2}{*}{ Infant age (mean weeks $\pm S D$ ) } & \multirow[t]{2}{*}{$7.92(3.67)$} & \multicolumn{2}{|l|}{ Current Diagnosis of Anxiety } & \multicolumn{2}{|l|}{ Mode of delivery } \\
\hline & & Yes & $140(19.7)$ & $\begin{array}{l}\text { Vaginal (without medical } \\
\text { intervention) }\end{array}$ & $359(50.6)$ \\
\hline Maternal Characteristic & $\begin{array}{l}\text { Value } n \\
(\%)\end{array}$ & No & $567(79.9)$ & Elective caesarean section & $134(18.9)$ \\
\hline Ethnicity & & Prefer not to say & $3(0.4)$ & Emergency caesarean section & $136(19.2)$ \\
\hline White & $676(95.2)$ & & & Vaginal birth (assisted delivery) & $81(11.4)$ \\
\hline Pakistani & $2(0.3)$ & \multicolumn{4}{|l|}{ Current Diagnosis of Depression } \\
\hline Black African & $2(0.3)$ & Yes & $85(12.0)$ & \multicolumn{2}{|l|}{ Multiple birth } \\
\hline Black Caribbean & $1(0.1)$ & No & $621(87.5)$ & Yes & $9(1.3)$ \\
\hline Chinese & $3(0.4)$ & Prefer not to say & $4(0.6)$ & No & $701(98.7)$ \\
\hline Indian & $7(1.0)$ & & & & \\
\hline Black Other & $1(0.1)$ & \multicolumn{2}{|l|}{ Current Diagnosis of PTSD } & \multicolumn{2}{|c|}{ Infant medical complications since birth } \\
\hline \multirow[t]{2}{*}{ Other or prefer not to say } & $18(2.5)$ & Yes & $28(3.9)$ & Yes & $161(22.7)$ \\
\hline & & No & $676(95.2)$ & No & $546(76.9)$ \\
\hline Marital Status & & Prefer not to say & $6(0.8)$ & & \\
\hline Married or Co-habiting & $667(93.9)$ & & & COVID-19 Characteristic & $\begin{array}{l}\text { Value } \mathrm{n} \\
\text { (\%) }\end{array}$ \\
\hline \multirow[t]{2}{*}{$\begin{array}{l}\text { Single, Separated/Divorced, or } \\
\text { Widowed }\end{array}$} & $43(6.1)$ & Postpartum Anxiety (PPA) & $\begin{array}{l}\text { Value } \mathrm{n} \\
\text { (\%) }\end{array}$ & Suspected COVID-19 & \\
\hline & & $\begin{array}{l}\text { Overall PPA PSAS-RSF-C Mean }( \pm \\
\text { SD) }\end{array}$ & $\begin{array}{l}24.84 \\
(6.28)\end{array}$ & Yes & $49(6.9)$ \\
\hline Occupation ${ }^{a}$ & & & & No & $660(93.0)$ \\
\hline In paid employment & $633(89.2)$ & \multicolumn{2}{|c|}{ Feeling that PPA has been affected by COVID-19 } & Prefer not to say & $1(0.1)$ \\
\hline \multirow[t]{2}{*}{ Not in paid employment } & $77(10.8)$ & Yes & $438(61.7)$ & & \\
\hline & & No & $267(37.6)$ & Tested for COVID-19 & \\
\hline Education Attainment & & Prefer not to say & $5(0.7)$ & Yes & $2(0.3)$ \\
\hline University-level education & $455(64.1)$ & & & No & $47(6.6)$ \\
\hline School-level education & $230(32.4)$ & $\begin{array}{l}\text { PPA affected by COVID-19 Mean ( } \pm \\
\text { SD) }\end{array}$ & $7.33(1.82)$ & Not Applicable & $661(93.1)$ \\
\hline No qualifications & $10(1.4)$ & & & & \\
\hline \multirow[t]{2}{*}{ Other qualification } & $15(2.1)$ & \multicolumn{2}{|c|}{$\begin{array}{l}\text { Clinical anxiety diagnosis overall PSAS-RSF-C } \\
\text { Mean }( \pm S D)\end{array}$} & \multicolumn{2}{|l|}{$\begin{array}{l}\text { Family member suspected COVID- } \\
19\end{array}$} \\
\hline & & Yes & $\begin{array}{l}28.35 \\
(7.45)\end{array}$ & Yes & $125(17.6)$ \\
\hline Living Status & & No & $\begin{array}{l}23.90 \\
(5.60)\end{array}$ & No & $584(82.3)$ \\
\hline Own property & $453(63.8)$ & & & Prefer not to say & $1(0.1)$ \\
\hline Rent - privately (from private landlord) & $147(20.7)$ & Infant Characteristics & $\begin{array}{l}\text { Value } \mathrm{n} \\
(\%)\end{array}$ & & \\
\hline $\begin{array}{l}\text { Rent - local authority (state-owned } \\
\text { housing) }\end{array}$ & $63(8.9)$ & Timing of birth & & $\begin{array}{l}\text { Family member tested for COVID- } \\
19\end{array}$ & \\
\hline Live with parents & $36(5.1)$ & Premature (<37 weeks) & $54(7.4)$ & Yes & $10(1.4)$ \\
\hline \multirow[t]{2}{*}{ Other } & $11(1.5)$ & Term ( $\geq 37$ to $\leq 42$ weeks) & $652(91.8)$ & No & $115(16.2)$ \\
\hline & & Post Term (> 42 weeks) & $4(0.6)$ & Not applicable & $585(82.4)$ \\
\hline \multicolumn{6}{|l|}{ Household Size (incl. participant) } \\
\hline 2 people & $39(5.5)$ & Birth order & & \multicolumn{2}{|c|}{$\begin{array}{l}\text { Birth experience affected by UK Government } \\
\text { 'lockdown' restrictions }\end{array}$} \\
\hline
\end{tabular}


Table 1 Maternal, Infant, and COVID-19 Characteristics ( $N=710$ Mothers) (Continued)

\begin{tabular}{llllll}
\hline 3 people & $296(41.7)$ & 1 st & $351(49.4)$ & Yes & $242(34.1)$ \\
4 people & $260(36.6)$ & 2nd & $265(37.3)$ & No & $464(65.4)$ \\
5 or more people & $115(16.2)$ & 3rd and after & $93(13.1)$ & Prefer not to say & $4(0.6)$ \\
& & Prefer not to say & $1(0.1)$ & & \\
\hline
\end{tabular}

aparticipants provided answers to the question: 'What is your occupation? (If you are currently on maternity leave, what was your occupation prior to this)' bWomen who answered 'Yes' to their feelings of PPA being affected by COVID-19, were then asked to rate on a scale of 1-10 (whereby $1=$ much less anxious to $10=$ much more anxious) of how much they felt their feelings had been affected

completion of the survey, participants were provided with a full electronic debrief with signposting to relevant support information, and were entered into a $£ 25$ prize draw.

\section{Instruments}

\section{Postpartum Specific Anxiety Scale - Research Short Form -} for global Crises [PSAS-RSF-C]

The original principal component analysis (PCA) provides factor loadings showing the strength of the relationship between the underlying PSAS factors and individual items [19]. Researchers commonly use factor loading as a scale reduction technique, preserving items with the highest factor loading [27, 28]. In-line with NICE guidelines [11], 12-items from the PSAS were selected on the basis of a review of their factor loading. The three items with the highest factor loadings (all > 0.50 ), were selected from each sub-scale. In the original validation of the PSAS [19], the third and fourth items from Factor 1 possessed identical factor loadings (0.66). In-line with guidelines for psychometric scale development [28, 29], Item 3 was selected over Item 4 for the PSAS-RSF-C, as it provided Factor 1 with a more comprehensive assessment of Maternal Competence and Attachment Anxieties. The final 12-items of the Englishlanguage PSAS-RSF-C can be found in Table 2 .

\section{Edinburgh Postnatal Depression Scale [EPDS]}

The EPDS [30] is a 10-item self-report questionnaire which screens for postnatal depressive symptomatology. It is commonly utilised and recommended screening scale for postnatal depression. Scored out of 30, higher levels of postpartum depressive symptoms are indicated by high scores on the scale, with a score of greater than 10 indicative of a probable postpartum depression. Items three, four, and five cluster on an anxiety factor [EPDS$3 \mathrm{~A}]$ to indicate postpartum anxiety $[31,32]$. Scored out of nine, with scores of six or above indicating probable postpartum anxiety.

\section{State-Trait Anxiety Inventory - State scale [STAI-S]}

The STAI-S is a sub-scale of the STAI [33]. It is a 20item self-report questionnaire which measures situational anxiety. The STAI-S is a valid and reliable measure used frequently in perinatal samples of women [18].
It is scored out of 80 , on a four point Likert scale, with higher scores indicating higher levels of anxiety.

\section{Parenting Sense of Competence scale [PSoC]}

The PSoC is a frequently used measure of parenting competence, with seven items and two sub-scales [34]. Each item is rated on a six-point Likert scale with higher scores indicating a higher sense of parenting competence.

\section{Method of analysis}

Data taken from The UK PRaM Study $(N=710)$ were randomly split into two samples: One for the exploratory factor analysis $(n=344)$, the other for the confirmatory factor analysis $(n=366)$.

\section{Exploratory factor analysis (group $1 ; n=344$ )}

Due to these data being ordinal (as scored on a fourpoint Likert scale), a parallel analysis was conducted using the simulated polychoric correlation matrix in order to identify the number of likely components in the data. Following this, a PCA with oblique rotation (oblimin) was conducted, again using the polychoric correlation matrix. Notably, results were identical when the raw data were analysed.

Confirmatory factor analysis (group 2; $n=366$ )

A confirmatory factor analysis was performed using MPLUS version 8.4 [35], using robust unweighted least squares estimation [36]. Items were free to load onto their corresponding latent factors, and latent factors were free to correlate with each other. Model fit was assessed using the Comparative Fit Index [CFI] and the Tucker-Lewis Index [TLI], where values of above .90 are deemed 'acceptable', and values above .95 are deemed 'good'. The Root Mean Square Error of Approximation (RMSEA) [37] indicates a good fit $(<.05)$, a fair fit $(.05$ $<>.08)$, a mediocre fit $(.08<>.10)$, and a poor fit $(>.10)$. The Standardized Root Mean Square Residual [SRMR] is considered a good fit where values are less than .08 [38]. Modification indices were also inspected, and if in excess of 20, covariance pathways were added between error terms (if conceptually appropriate, items loaded onto the same factor). 
Table 2 The English Language PSAS-RSF-C with Five Translations

\begin{tabular}{lllllll}
\hline Item & English Version & Italian Version [PSAS- & French Version [PSAS- & Spanish Version & Chinese & Dutch Version [PSAS- \\
Number & [PSAS-RSF-C] & IT-RSF-C] & FR-RSF-C] & [PSAS-ES-RSF-C] & $\begin{array}{l}\text { Version } \\
\text { NPS-RSF-C] }\end{array}$ \\
& & & & [PSAS-CN- \\
& & & RSF-C]
\end{tabular}

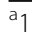

I have worried more about my relationship with my partner than before my baby was born.

2. I have worried about

my baby's weight.

3. I have worried about getting my baby into a routine.

4. I have worried about my baby being accidentally harmed by someone or something.

5. | have felt unconfident or incapable of meeting my baby's basic care needs.

6. I have had negative thoughts about my relationship with my baby.

7. I have worried about my baby's milk intake.

8. I have worried that my baby will stop breathing while sleeping.

9. I have felt that my baby would be better cared for by someone else.

${ }^{a} 10 . \quad$ | have felt resentment towards my partner.

11. I have repeatedly checked on my sleeping baby.

12. I have felt tired even after a good amount of rest. accidentalmente al mio
Mi sono preoccupata di più del rapporto con il mio partner rispetto a prima che il mio bambino nascesse.

Mi sono preoccupata per il peso del mio bambino.

Mi sono preoccupata di far avere al mio

bambino una sua routine.

Ho avuto pensieri negativi rispetto alla relazione con il mio bambino.

Je me suis davantage inquiétée de ma relation avec mon partenaire qu'avant la naissance de mon bébé.

Je me suis inquiétée du poids de mon bébé.

Je me suis inquiétée d'arriver à instaurer une routine avec mon bébé

Mi sono preoccupata che qualcuno o qualcosa possa nuocere bambino.

Mi sono sentita insicura o incapace di soddisfare i bisogni primari del mio bambino.

Mi sono preoccupata per la quantità di latte assunta dal mio bambino.

Ho avuto paura che il mio bambino smettesse di respirare durante il sonno.

Ho pensato che il mio bambino sarebbe meglio accudito da qualcun altro.

Ho provato risentimento J'ai eu du ressentiment nei confronti del mio partner.

Ho ripetutamente controllato il mio bambino mentre dormiva.

Mi sono sentita stanca anche dopo una buona quantità di riposo.
J'ai craint que mon bébé puisse être accidentellement blessé par quelqu'un ou quelque chose.

Je me suis sentie pas assez en confiance ou incapable de répondre aux besoins

fondamentaux de mon bébé.

J'ai eu des pensées négatives concernant ma relation avec mon bébé.

Je me suis inquiétée de la quantité de lait prise par mon bébé.

J'ai craint que mon bébé ne cesse de respirer pendant son sommeil.

J'ai senti que quelqu'un d'autre prendrait mieux soin de mon bébé envers mon partenaire.

Je suis allée surveiller de façon répétée mon bébé pendant son sommeil.

Je me suis sentie fatiguée même après beaucoup de repos.
Me ha preocupado más mi relación con mi pareja que antes de que naciera el bebé.

Me preocupa el peso de mi bebé. crear una rutina para mi bebé.

Me preocupa que alguien o algo, por accidente, haga daño a mi bebé

Me he sentido insegura o incapaz de satisfacer las necesidades básicas de mi bebé.

He tenido pensamientos negativos sobre mi relación con $\mathrm{mi}$ bebé.

Me preocupa la cantidad de leche que toma mi bebé

Me preocupa que mi bebé deje de respirar mientras duerme.

He sentido que $m$ bebé estaría mejor cuidado por otra persona.

He sentido resentimiento hacia mi pareja.

He comprobado repetidas veces el estado de mi bebé mientras dormía.

Me he sentido cansada incluso después de un buen descanso.
我比宝宝出 $1 k$ heb me meer zorgen 生之前更担 gemaakt over mijn 心我与伴侣 relatie met mijn partner 的关系 dan voordat mijn baby was geboren.

我担心宝宝 I heb me zorgen 的体重 gemaakt over het gewicht van mijn baby.

我为让宝宝 $\mid k$ heb me zorgen 养成习惯而 gemaakt over het 发愁等 krijgen van een routine voor mijn baby.

我担心宝宝 Ik heb me zorgen 会受到某人 gemaakt dat mijn baby 或某物的意 per ongeluk bezeerd 外伤害 raakt door iets of iemand anders.

我感觉我没 $\mid k$ heb me onzeker of 有信心或能 onbekwaam gevoeld 力满足宝宝 om aan de

的基本护理 basisbehoeften van mijn 需求 baby te voldoen.

我对我与宝 Ik heb negatieve 宝的关系有 gedachten gehad over 过消极的想 de relatie die ik met 法 mijn baby heb.

我担心宝宝 I h heb me zorgen 的牛奶摄入 gemaakt over de 量 hoeveelheid melk die mijn baby drinkt.

我担心宝宝 Ik heb me zorgen 睡觉时会停 gemaakt dat mijn baby 止呼吸 zal stoppen met ademen tijdens het slapen.

我感觉我的 I h heb het gevoel gehad 宝宝最好由 dat mijn baby beter zou 别人来照顾 worden verzorgd door iemand anders.

我对我的伴 $\mid k$ heb gevoelens van 侣感到怨恨 wrok gehad naar mijn partner.

宝宝睡觉时, Ik heb herhaaldelijk mijn 我会反复查 slapende baby 看他/她ｇecontroleerd.

使得到充 $1 \mathrm{k}$ heb me moe gevoeld, 分休息，我 zelfs na een goede 仍感觉很累 hoeveelheid rust. 


\section{Internal consistency}

Internal reliability of the full scale and each subscale was estimated by computing McDonald's $\omega$ through the polychoric correlation matrix. This was computed for both data sets.

\section{Convergent validity}

Correlation analyses were performed to examine the associations between the PSAS-RSF-C and theoretically related measures of anxiety (i.e. EPDS-A; STAI-S), depression (i.e. EPDS), and parenting competence (i.e. PSoC).

\section{Preliminary screening accuracy}

A receiver operating characteristic [ROC] analysis was undertaken to distinguish between those with and without a self-reported current clinical diagnosis of anxiety.

\section{Results}

\section{Factor structure of the PSAS-RSF-C}

The factor structure of the PSAS-RSF-C (Table 3) was examined using data from all the participants in Group $1 \quad(n=344)$. The parallel analysis suggested there were four factors which are consistent with the original 51-item measure. Sampling adequacy for the 12-item scale was excellent (Kaiser-Meyer-Olkin; $\mathrm{KMO}=0.80)$ and Bartlett's test of sphericity demonstrated correlations between items were large enough for PCA $\left(\chi^{2}(66)=284.17, p<.001\right)$. The PCA revealed four factors, which in combination explained $75 \%$ of the total variance. The UK-based PSAS Working Group [VF, SAS, JAH, JCGH, SMD, PaCh] conducted a theoretical review of the factor loadings after oblique (direct oblimin) rotation, which revealed that the factor structure of the PSAS-RSF-C was identical in nature to that of the original PSAS. Three items loaded onto each of the four factors which they belonged to in the long form: Maternal Competence and Attachment Anxieties; Infant Safety and Welfare Anxieties; Practical Infant Care Anxieties; and Psychosocial Adjustment to Motherhood. The four factors had good reliability, with McDonald's $\omega$ ranging from .74 to .88 (see Table 3 ). Furthermore, the overall scale had good reliability (McDonald's $\omega=.87$ ).

\section{Confirmation of factor structure}

The initial model was a moderate to good fit of the data $(\mathrm{CFI}=.928, \quad \mathrm{TLI}=.901, \quad \mathrm{RMSEA}=.096, \quad$ SRMR $=.067)$. Modification indices indicated a covariance should be added between three pairs of residuals (Fig. 2). As a result, the model fit improved $(\mathrm{CFI}=.973, \mathrm{TLI}=.960$, RMSEA $=.055$, SRMR $=.045$ ). All items significantly loaded onto each factor $(p<.001$; see Fig. 2 for the standardised factor loadings). The overall scale retained good reliability (McDonald's $\omega=.87$ ).

Table 3 Factor structure of the PSAS-RSF-C

\begin{tabular}{|c|c|c|c|c|}
\hline \multirow[b]{2}{*}{ Scale item } & \multicolumn{4}{|c|}{ Rotated components } \\
\hline & 1 & 2 & 3 & 4 \\
\hline \multicolumn{5}{|l|}{ Factor 1: Maternal Competence and Attachment Anxieties } \\
\hline 1. I have had negative thoughts about the relationship with my baby & 0.85 & -0.02 & -0.01 & 0.13 \\
\hline 2.I have felt that my baby would be better cared for by someone else & 0.85 & 0.04 & 0.06 & 0.04 \\
\hline 3.I have felt unconfident or incapable of meeting my baby's basic care needs & 0.76 & 0.03 & 0.25 & 0.01 \\
\hline \multicolumn{5}{|l|}{ Factor 2: Infant Safety and Welfare Anxieties } \\
\hline 4. I have worried about my baby being accidentally harmed by someone or something else & 0.40 & 0.69 & -0.06 & -0.05 \\
\hline 5. I have repeatedly checked on my sleeping baby & -0.26 & 0.86 & 0.14 & 0.08 \\
\hline 6. I have worried that my baby will stop breathing while sleeping & 0.09 & 0.91 & -0.03 & 0.00 \\
\hline \multicolumn{5}{|l|}{ Factor 3: Practical Infant Care Anxieties } \\
\hline 7. I have worried about my baby's milk intake & 0.11 & 0.06 & 0.86 & -0.03 \\
\hline 8. I have worried about my baby's weight & 0.00 & 0.00 & 0.92 & 0.01 \\
\hline 9. I have worried about getting my baby into a routine & 0.28 & -0.04 & 0.51 & 0.19 \\
\hline \multicolumn{5}{|l|}{ Factor 4: Psychosocial Adjustment to Motherhood } \\
\hline 10. I have felt resentment towards my partner & 0.17 & 0.04 & -0.19 & 0.80 \\
\hline 11. I have felt tired even after a good amount of rest & -0.16 & 0.11 & 0.21 & 0.68 \\
\hline 12. I have worried more about my relationship with my partner than before my baby was born & 0.03 & -0.05 & 0.06 & 0.84 \\
\hline$\%$ of variance explained & 22 & 18 & 18 & 17 \\
\hline McDonald's Omega & .88 & .83 & .82 & .74 \\
\hline
\end{tabular}

All significant loadings in bold 


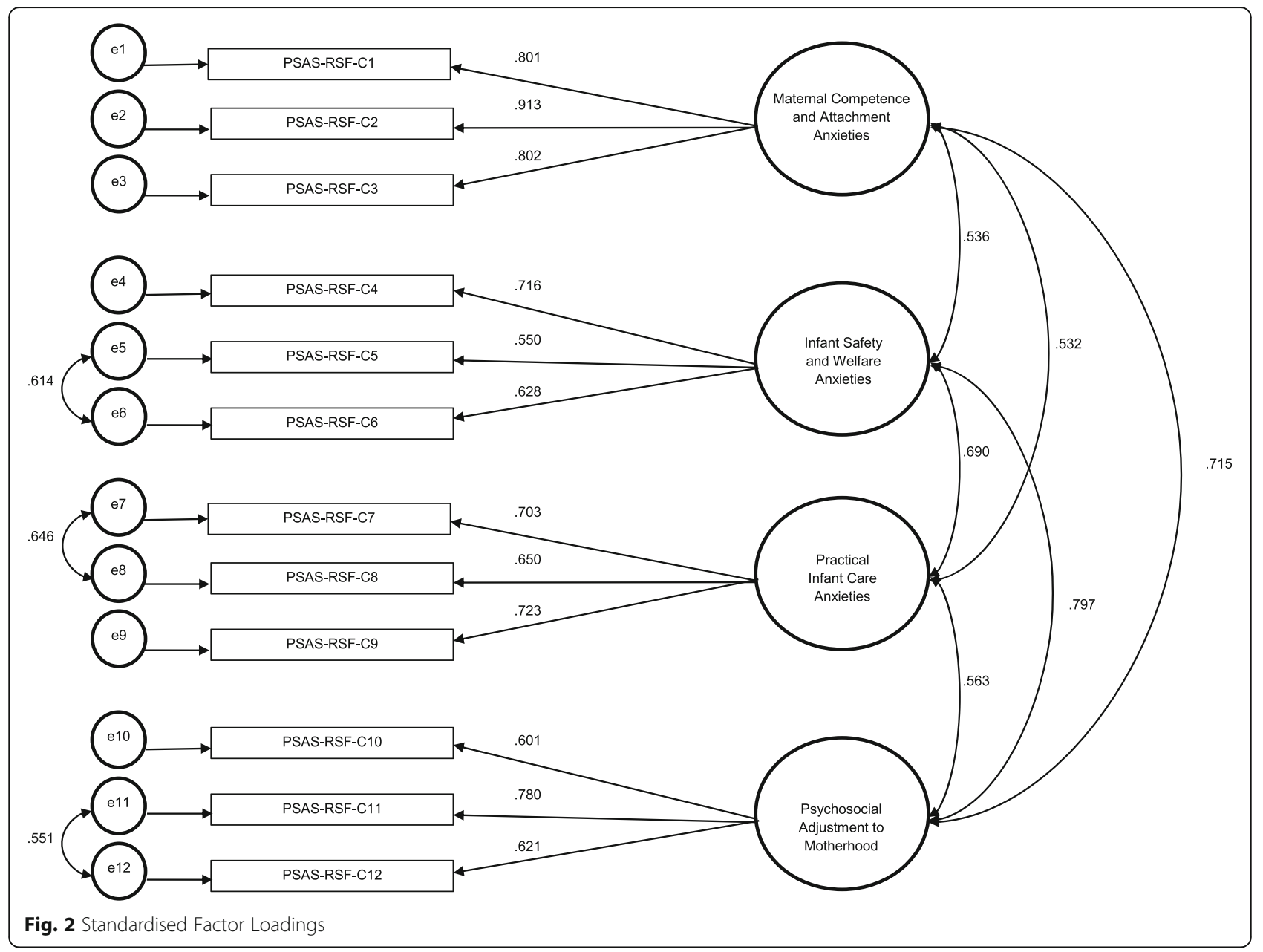

\section{Convergent validity}

The participants who completed all convergent measures were included in these analyses. The PSAS-RSF-C total score was significantly correlated with theoretically related measures of anxiety (i.e. EPDS-A $[n=710]$; STAI-S $[n=709]$ ), depression (i.e. EPDS $[n=710]$ ), and parenting competence (i.e. PSoC $[n=666]$ ) indicating good convergent validity (Table 4 ).

\section{Preliminary screening accuracy of PSAS-RSF-C}

First, An independent samples t-test demonstrated that the mean PSAS-RSF-C scores for those with a self-reported clinical diagnosis of anxiety $(n=140$; $\mathrm{M}=28.35 ; \mathrm{SD}=7.45)$ were significantly higher than

Table 4 Pearson product-moment correlations demonstrating convergent validity between the PSAS-RSF-C and other validated measures of maternal mental health

\begin{tabular}{lcccc}
\hline & EPDS-A & STAI-S & EPDS & PSOC \\
\hline PSAS-RSF-C & $.57^{*}$ & $.62^{*}$ & $0.67^{*}$ & $-0.54^{*}$ \\
\hline
\end{tabular}

${ }^{*} p<.001$ (one-tailed) those without a self-reported clinical diagnosis $(n=$ $567 ; \mathrm{M}=23.93 ; \mathrm{SD}=5.60) \mathrm{t}(705)=-7.79 ; p<.001$. Then, to preliminarily evaluate the performance of the PSAS-RSF-C in distinguishing between those with or without a current clinical diagnosis of anxiety, a Receiver Operating Characteristic [ROC] analysis was conducted. A statistically significant ROC curve $(\mathrm{AUC}=.68 ; \mathrm{SE}=.03 ; \mathrm{p}<.001 ; 95 \%$ CI .62 to .73$)$ revealed the optimal cut-off PSAS-RSF-C score for detecting clinical levels of anxiety was 26 out of a total of 48 with a sensitivity and specificity of .62 and .64 , respectively (Fig. 3).

\section{International use of the PSAS-RSF-C}

Translation of the PSAS follows traditional methods of psychometric scale translation [39-42]. In brief, this requires at least three researchers to supply separate versions of the PSAS into the desired language. These translations are then given to an independent backtranslator [39], who is unfamiliar with the PSAS. The back-translator will select the most eloquent translation of each item from the three translated versions [40]. 


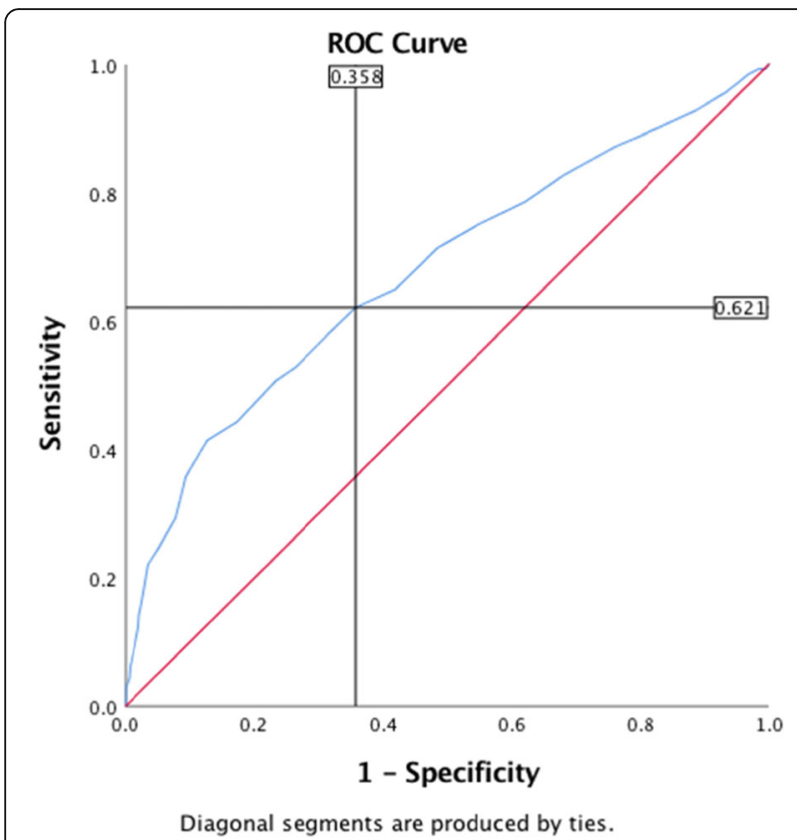

Fig. 3 Receiver Operating Characteristic $[R O C]$ curve analysis. Area under the curve $=0.68$

This single back-translation is then checked with the UK-based PSAS Working Group, who checks the backtranslation against the original PSAS for inconsistencies and intended meaning [41]. The items which make up this final back-translated version are the items which will be used for the final translated version. Inconsistencies at any stage of the translation process are discussed amongst the translating team, with irreconcilable discrepancies being referred to the UK-based PSAS Working Group [42].

We therefore have selected the same 12-items in the currently unvalidated, but translated Italian, French, Spanish, Chinese, and Dutch versions of the 51-item PSAS to form a PSAS-RSF-C for each country (PSASIT-RSF-C, PSAS-FR-RSF-C, PSAS-CN-RSF-C, PSAS-ESRSF-C, and PSAS-NL-RSF-C, respectively, Table 2).

\section{Discussion}

The primary aim of the current study was to develop a brief and accessible measure of postpartum anxiety. We aimed to validate the tool for research use in global crises such as the current pandemic, and further explore its scope for clinical usage. To that end, we developed a 12item short-form of the English-language PSAS and examined the psychometric properties and diagnostic accuracy of the measure in two samples of women during the UK 'lockdown'.

The selection of items for the short-form was informed by the aim of preserving the originally proposed four factor structure of the PSAS [19] with domains of both maternal- and infant-focused anxiety. This was in order to maintain breadth of content coverage, in-line with psychometric guidance [27-29]. The validation of the English-language PSAS-RSF-C shows promising psychometric properties which would be useful for rapid measurement of maternal anxiety in the current global crisis, and any crises which may occur in the future.

The current findings demonstrate the robustness of the PSAS across diverse psycho-social contexts. Exploratory factor analyses in one sample demonstrated a simple four-factor structure, identical to the original 51item version [19], expressed as (1) Competence and Attachment Anxieties; (2) Infant Safety and Welfare Anxieties; (3) Practical Baby Care Anxieties; and (4) Psychosocial Adjustment to Motherhood. Confirmatory factor analyses in a second sample demonstrated an excellent fit of the measurement model. The overall PSAS-RSF-C and its sub-scales demonstrated good reliability in both samples. This suggests the types of anxieties new mothers are experiencing during the current crisis are comparable to those which occurred prepandemic, and are maternal- and infant-focused in nature. This indicates a continued critical need to further understand the experience and impact of perinatal anxiety during the current crisis [3, 43-45].

The diagnostic accuracy of the original 51-item PSAS to detect individuals with self-reported diagnosis of anxiety was examined by means of ROC analyses [19]. To our knowledge, there are no other measures of anxiety validated during the current global COVID-19 pandemic, with which to compare these findings. However, when compared to the original 51-item PSAS, the results of this study indicate a good and comparably good diagnostic accuracy for the PSAS-RSF-C. We envisage the PSAS-RSF-C can be applied to a clinical setting to assist healthcare professionals in identifying mothers with problematic anxiety, as part of a broader clinical assessment. Therefore, we propose a cut-off score of 26 which provides a good balance between the sensitivity and specificity of the tool [46]. However, we recognise mental health may be elevated during the current pandemic [3$6,8,9,26]$, and as such, clinical judgement should be used in parallel with PSAS-RSF-C scores.

The translated versions of the PSAS-RSF-C into five global languages (Italian, French, Chinese, Spanish, and Dutch) will enable a broad use of the tool in order for researchers and clinicians globally to assess maternal mental health when undertaking rapid response research and clinical assessments during the pandemic. Whilst each translation requires subsequent validation, work is already underway to do so. This will allow for a more comprehensive assessment of global maternal mental health during the COVID-19 pandemic, as well as 
providing the opportunity to compare between datasets utilising the same scale items, in different languages.

\section{Strengths, limitations, and future directions}

A major strength of this study is that, to the authors' knowledge, this is the first postpartum-specific psychometric scale to be validated for use during the COVID-19 global pandemic, and in being so, is also one of the first perinatal psychometric tools to be validated in the current crisis, with others including the Pandemic-Related Pregnancy Stress Scale [47]. This means postpartum anxiety can be effectively measured during this pandemic, and similar global crises in the future. Furthermore, many psychometric studies inappropriately use factor analyses developed for interval-level data, when the psychological construct, and the measurement of it, is, in fact, ordinal in nature. A strength of this study is the use of a polychoric correlation matrix, which overcomes this common, but often statistically inappropriate practice [48]. Additionally, we report McDonald's Omega, to appraise reliability, as opposed to Cronbach's Alpha, which focuses on the greatest lower bounds estimate [49]. Finally, providing a validated 12 -item research shortform of the PSAS means it can be more readily adopted into studies containing a large battery of tests during COVID-19 and other such global crises, without being prohibitively long. Whilst the diagnostic accuracy was found to be good in this validation study, we recommend erring on the side of caution when making clinical decisions based on this research short-form alone.

A limitation is the use of an on-line convenience sample. This recruitment, whilst pragmatic for the rapid response nature of this research, lacked sampling control. The sample were predominantly white, married women, with university education and professional occupations. There was also a high proportion of assisted vaginal births and caesarean sections, and whilst the cause of this remains unknown, it has been suggested women have delayed seeking care during the pandemic, leading to higher incidence rates of obstetric complications [50]. The psychometric properties of the PSASRSF-C may, therefore, vary in other populations and it should be subject to replication studies using diverse samples.

Future research efforts should be directed towards the global validation of the PSAS and the PSAS-RSF-C. Whilst the five translations of the PSAS-RSF-C presented in this paper have not yet been subjected to validation studies, validation work must be conducted to ensure the validity and reliability of both the 12-item PSAS-RSF-C and the 51-item PSAS in other languages.
Previous work examining the predictive validity of the PSAS [20, 22] consistently finds it is a more powerful predictor of perinatal outcomes than a general measure (e.g. STAI [33]). Consequently, this tool would be useful in longitudinal studies aiming to better understand the persistent mental health impact of the pandemic (and other such global crises in the future) on maternal and infant outcomes. Preliminary work demonstrates the sub-scales of the PSAS have differential effects on maternal and infant outcomes [51]. Further investigations of the sub-scales could provide greater level of detail in terms of identifying specific risk factors and mechanisms of PPA and may offer opportunities for targeted intervention.

\section{Conclusion}

Following the calls for mental health to be addressed during and after the global crisis, the PSAS-RSF-C offers one way in which to reliably measure maternal mental health in the postpartum period. To the best of the authors' knowledge, this is the first postpartum-specific psychometric scale to be validated for use during the COVID-19 pandemic, and in being so, is also one of the first perinatal psychometric tools to be validated during this current crisis. In doing so, we provide opportunity for researchers and clinicians to measure postpartum anxiety accurately, whilst laying foundations for further global psychometric work to be undertaken during the current crisis, and in those which will present in the future.

\section{Abbreviations}

EPDS: Edinburgh Postnatal Depression Scale; NCCMH: National Collaborating Centre for Mental Health; NICE: National Institute of Health and Care Excellence; PCoS: Parenting sense of competence scale; PPA: Postpartum anxiety; PSAS: Postpartum Specific Anxiety Scale; PSAS-RSF-C: Postpartum Specific Anxiety Scale - Research Short Form - for global Crises.;

RCOG: Royal College of Obstetricians and Gynaecologists; SARS-CoV-2: Severe Acute Respiratory Syndrome Coronavirus 2 (a.k.a. COVID-19); STAI: State-Trait Anxiety Inventory; UKRI: UK Research and Innovation; WHO: World Health Organization

\section{Acknowledgements \\ We would like to extend our thanks to Ms. Philippa Davie (Institute for Psychiatry, Psychology \& Neuroscience, King's College London), and Ms. Arianna Menardi (Padova Neuroscience Center, Università degli Studi di Padova) for their assistance with translations.}

\section{Authors' contributions}

Conceptualization: Sergio A. Silverio \& Victoria Fallon. Study Design: Siân M. Davies, Victoria Fallon, Joanne A. Harrold. Data Collection: Siân M. Davies, Victoria Fallon, Data Analysis: Sergio A. Silverio, Victoria Fallon, Siân M. Davies \& Paul Christiansen. Data Interpretation: All authors. Writing: Sergio A. Silverio (lead), Siân M. Davies, Victoria Fallon. All authors critically revised the manuscript and agreed to its publication.

\section{Authors' information}

Sergio A. Silverio (King's College London) is supported by the National Institute for Health Research Applied Research Collaboration South London [NIHR ARC South London] at King's College Hospital NHS Foundation Trust. The views expressed are those of the authors and not necessarily those of the NIHR or the Department of Health and Social Care. 


\section{Funding}

This study received no funding.

\section{Availability of data and materials}

The datasets used and/or analysed during the current study are available from the corresponding author on reasonable request.

\section{Ethics approval and consent to participate}

Ethical approvals were sought and granted from the University of Liverpool Research Ethics Committee [ref:- IPHS/7630]. The survey method was utilised in accordance with relevant guidelines and regulations, with all psychometric scales having been previously validated scales or versions of them. The on-line survey content and method was all approved by the Research Ethics Committee. Informed consent was obtained from all study participants at the beginning of the study, and participants were made aware of their right to withdraw.

\section{Consent for publication}

All participants consented to their data being published as part of this study's analysis.

\section{Competing interests}

No conflicts of interest or competing interests have been declared by any author.

\section{Author details}

${ }^{1}$ Department of Women \& Children's Health, School of Life Course Sciences, King's College London, London, UK. 'Department of Psychology, Institute of Population Health, University of Liverpool, Liverpool, UK. ${ }^{3}$ Elizabeth Garrett Anderson Institute for Women's Health, Faculty of Population Health Sciences, University College London, London, UK. ${ }^{4}$ School of Psychology, Faculty of Health, Liverpool John Moores University, Liverpool, UK. ${ }^{5}$ Division of Psychology and Mental Health, School of Health Sciences, The University of Manchester, Manchester, UK. 'Departamento de Psicología Social, Psicología del Trabajo y Psicología Diferencial, Facultad de Psicología, Universidad Complutense de Madrid, Madrid, Spain. ${ }^{7}$ Humanitas San Pio X, Milan, Italy. ${ }^{8}$ Collaborative Innovation Center of Assessment for Basic Education Quality, Beijing Normal University, Beijing, China. 'Department of Cognitive Neuroscience, Donders Institute for Brain, Cognition and Behaviour, Radboud University Medical Center, Nijmegen, The Netherlands. ${ }^{10}$ Dipartimento di Scienze Cliniche e Sperimentali, Università degli Studi di Brescia, Brescia, Italy. ${ }^{11}$ Laboratoire Psychopathologie et Processus de Santé, Institut de Psychologie, Université de Paris, Paris, France. ${ }^{12}$ National Research Institute for Family Planning, Beijing, China. ${ }^{13}$ School of Psychology, Faculty of Medicine and Health, University of Leeds, Leeds, UK.

Received: 3 November 2020 Accepted: 20 January 2021

Published online: 08 February 2021

\section{References}

1. Royal College of Obstetricians \& Gynaecologists. Coronavirus (COVID-19) pregnancy and women's health. 2020. https://www.rcog.org.uk/en/ guidelines-research-services/coronavirus-covid-19-pregnancy-and-womenshealth/.

2. Zaigham M, Andersson O. Maternal and perinatal outcomes with COVID-19: a systematic review of 108 pregnancies. Acta Obstet Gynecol Scand. 2020; 99(7):823-9. https://doi.org/10.1111/aogs.13867.

3. Matvienko-Sikar K, Meedya S, Ravaldi C. Perinatal mental health during the COVID-19 pandemic. Women Birth. 2020;33(4):309-10. https://doi.org/10. 1016/j.wombi.2020.04.006.

4. D'Agostino A, Demartini B, Cavallotti S, Gambini O. Mental health services in Italy during the COVID-19 outbreak. Lancet Psychiatry. 2020;7(5):385-7. https://doi.org/10.1016/S2215-0366(20)30133-4

5. Qiu J, Shen B, Zhao M, Wang Z, Xie B, Xu Y. A nationwide survey of psychological distress among Chinese people in the COVID-19 epidemic: implications and policy recommendations. Gen Psychiatry. 2020:33(2):1-3. https://doi.org/10.1136/gpsych-2020-100213

6. Brooks SK, Webster RK, Smith LE, Woodland L, Wessely S, Greenberg N, Rubin GJ. The psychological impact of quarantine and how to reduce it: rapid review of the evidence. Lancet. 2020:395(10227):912-20. https://doi. org/10.1016/S0140-6736(20)30460-8.
7. The Lancet Psychiatry. Isolation and inclusion. Lancet Psychiatry. 2020;7(5): 371. https://doi.org/10.1016/S2215-0366(20)30156-5.

8. The Lancet Psychiatry. Mental health and COVID-19: change the conversation. Lancet Psychiatry. 2020;7(6):463. https://doi.org/10.1016/S22150366(20)30194-2.

9. Zeng LN, Chen LG, Yang CM, Zeng LP, Zhang LY, Peng TM. Mental health care for pregnant women in the COVID-19 outbreak is urgently needed. Women Birth. 2020:1-2. https://doi.org/10.1016/j.wombi.2020.03.009.

10. World Health Organisation. Gender and women's mental health. 2016. https://www.who.int/mental_health/prevention/genderwomen/en/

11. National Collaborating Centre for Mental Health. Antenatal and postnatal mental health: clinical management and service guidance (updated edition). In: National Institute for Health and Care Excellence (commissioners). National Clinical Guideline Number 192. London: The British Psychological Society and The Royal College of Psychiatrists; 2018.

12. Fallon V, Groves R, Halford JC, Bennett KM, Harrold JA. Postpartum anxiety and infant-feeding outcomes: a systematic review. J Hum Lact. 2016;32(4): 740-58. https://doi.org/10.1177/0890334416662241.

13. Mertesacker B, Bade U, Haverkock A, Pauli-Pott U. Predicting maternal reactivity/sensitivity: the role of infant emotionality, maternal depressiveness/anxiety, and social support. Infant Ment Health J. 2004:25(1): 47-61. https://doi.org/10.1002/imhj.1008.

14. van Bussel JC, Spitz B, Demyttenaere K. Anxiety in pregnant and postpartum women. An exploratory study of the role of maternal orientations. J Affect Disord. 2009;114(1-3):232-42. https://doi.org/10.1016/j.jad.2008.07.018.

15. Coplan RJ, O'Neil K, Arbeau KA. Maternal anxiety during and after pregnancy and infant temperament at three months of age. J Prenatal Perinatal Psychol Health. 2005;19(3):199.

16. Lonstein JS. Regulation of anxiety during the postpartum period. Front Neuroendocrinol. 2007;28(2-3):115-41. https://doi.org/10.1016/j.yfrne.2007. 05.002.

17. Glasheen C, Richardson GA, Fabio A. A systematic review of the effects of postnatal maternal anxiety on children. Arch Women Ment Health. 2010; 13(1):61-74. https://doi.org/10.1007/s00737-009-0109-y

18. Meades $R$, Ayers $S$. Anxiety measures validated in perinatal populations: a systematic review. J Affect Disord. 2011;133(1-2):1-5. https://doi.org/10. 1016/j.jad.2010.10.009

19. Fallon V, Halford JC, Bennett KM, Harrold JA. The postpartum specific anxiety scale: development and preliminary validation. Arch Women Ment Health. 2016:19(6):1079-90. https://doi.org/10.1007/s00737-016-0658-9.

20. Fallon V, Halford JC, Bennett KM, Harrold JA. Postpartum-specific anxiety as a predictor of infant-feeding outcomes and perceptions of infant-feeding behaviours: new evidence for childbearing specific measures of mood. Arch Women Ment Health. 2018;21(2):181-91. https://doi.org/10.1007/s00737-0170775-0.

21. Fallon V, Silverio SA, Halford JC, Bennett KM, Harrold JA. Postpartum-specific anxiety and maternal bonding: further evidence to support the use of childbearing specific mood tools. J Reprod Infant Psychol. 2019:1-11. https://doi.org/10.1080/02646838.2019.1680960.

22. Duran S. Postpartum specific anxiety scale (PSAS): reliability and validity of the Turkish version. Perspect Psychiatr Care. 2020;56(1):95-101. https://doi. org/10.1111/ppc.12385.

23. Bayri Bingol F, Bal MD, Aydin Ozkan S, Zengin O. The adaptation of the postpartum-specific anxiety scale into the Turkish language. J Reprod Infant Psychol. 2021;39(1):86-99. https://doi.org/10.1080/02646838.2019.1705265.

24. UK Research and Innovation. COVID-19 Rapid Response Rolling Call. 2020. https://webarchive.nationalarchives.gov.uk/20200923125555, https://mrc.ukri. org/funding/browse/ukri-nihr-covid-19/ukri-nihr-covid-19-rolling-call/.

25. Holmes EA, O'Connor RC, Perry VH, Tracey I, Wessely S, Arseneault L, Ballard C, Christensen H, Silver RC, Everall I, Ford T, John A, Kabir T, King K, Madan I, Michie S, Przybylski AK, Shafran R, Sweeney A, Worthman CM, Yardley L, Cowan K, Cope C, Hotopf M, Bullmore E. Multidisciplinary research priorities for the COVID-19 pandemic: a call for action for mental health science. Lancet Psychiatry. 2020;7(6):547-60. https://doi.org/10.1016/S22150366(20)30168-1.

26. Adhanom GT. Addressing mental health needs: an integral part of COVID-19 response. World Psychiatry. 2020;19(2):129-30. https://doi.org/10.1002/wps. 20768.

27. Smith GT, McCarthy DM, Anderson KG. On the sins of short-form development. Psychol Assess. 2000;12(1):102-11. https://doi.org/10.1037// 1040-3590.12.1.102. 
28. Stanton JM, Sinar EF, Balzer WK, Smith PC. Issues and strategies for reducing the length of self-report scales. Pers Psychol. 2002;55(1):167-94. https://doi. org/10.1111/j.1744-6570.2002.tb00108.x.

29. Streiner DL, Norman GR, Cairney J. Health measurement scales: a practical guide to their development and use. USA: Oxford University Press; 2015

30. Cox JL, Holden JM, Sagovsky R. Detection of postnatal depression: development of the 10-item Edinburgh postnatal depression scale. $\mathrm{Br}$ J Psychiatry. 1987;150(6):782-6. https://doi.org/10.1192/bjp.150.6.782.

31. Matthey S. Using the Edinburgh postnatal depression scale to screen for anxiety disorders. Depression Anxiety. 2008;25(11):926-31. https:/doi.org/10.1002/da.20415

32. Matthey S, Fisher J, Rowe H. Using the Edinburgh postnatal depression scale to screen for anxiety disorders: conceptual and methodological considerations. J Affect Disord. 2013;146(2):224-30. https://doi.org/10.1016/j. jad.2012.09.009.

33. Spielberger CD, Gorsuch RL, Lushene R, Vagg PR, Jacobs GA. Manual for the state-trait anxiety inventory. Palo Alto: Consulting Psychologists Press; 1983.

34. Gibaud-Wallston J, Wandersman LP. Development and utility of the parenting sense of competence scale. Paper presented at the annual meeting of the American Psychological Association, Toronto, Canada; 1978.

35. Muthén LK, Muthén BO. Mplus version 8.4; 2019.

36. Forero CG, Maydeu-Olivares A, Gallardo-Pujol D. Factor analysis with ordinal indicators: a Monte Carlo study comparing DWLS and ULS estimation. Struct Equ Model. 2009;16(4):625-41. https://doi.org/10.1080/ 10705510903203573

37. MacCallum RC, Browne MW, Sugawara HM. Power analysis and determination of sample size for covariance structure modeling. Psycho Methods. 1996;1(2):130-49. https://doi.org/10.1037/1082-989X.1.2.130.

38. Hu LT, Bentler PM. Cutoff criteria for fit indexes in covariance structure analysis: conventional criteria versus new alternatives. Struct Equ Model Multidiscip J. 1999;6(1):1-55. https://doi.org/10.1080/10705519909540118.

39. Sousa VD, Rojjanasrirat W. Translation, adaptation and validation of instruments or scales for use in cross-cultural health care research: a clear and user-friendly guideline. J Eval Clin Pract. 2011;17(2):268-74. https://doi. org/10.1111/j.1365-2753.2010.01434.x

40. Hilton A, Skrutkowski M. Translating instruments into other languages: development and testing processes. Cancer Nurs. 2002;25(1):1-7. https:// doi.org/10.1097/00002820-200202000-00001.

41. Gudmundsson E. Guidelines for translating and adapting psychological instruments. Nordic Psychol. 2009;61(2):29-45. https://doi.org/10.1027/19012276.61.2.29.

42. Maneesriwongul W, Dixon JK. Instrument translation process: a methods review. J Adv Nurs. 2004;48(2):175-86. https://doi.org/10.1111/j.1365-2648. 2004.03185.x.

43. Molgora S, Accordini M. Motherhood in the Time of Coronavirus: The Impact of the Pandemic Emergency on Expectant and Postpartum Women's Psychological Well-Being. Front Psychol. 2020;11:567155 2020; 11(567155):1-16. https://doi.org/10.3389/fpsyg.2020.567155.

44. Ostacoli L, Cosma S, Bevilacqua F, Berchialla P, Bovetti M, Carosso AR, Malandrone F, Carletto S, Benedetto C. Psychosocial factors associated with postpartum psychological distress during the Covid-19 pandemic: a cross-sectional study. BMC Pregnancy Childbirth. 2020;20(703):1-8. https://doi.org/10.1186/s12884-020-03399-5.

45. Hessami K, Romanelli C, Chiurazzi M, Cozzolino M. COVID-19 pandemic and maternal mental health: a systematic review and meta-analysis. J Matern Fetal Neonatal Med. 2020:1-8. https://doi.org/10.1080/14767058.2020. 1843155.

46. Plummer F, Manea L, Trepel D, McMillan D. Screening for anxiety disorders with the GAD-7 and GAD-2: a systematic review and diagnostic metaanalysis. Gen Hosp Psychiatry. 2016;39:24-31. https://doi. org/10.1016/j.genhosppsych.2015.11.005.

47. Preis H, Mahaffey B, Lobel M. Psychometric properties of the pandemicrelated pregnancy stress scale (PREPS). J Psychosom Obstet Gynaecol. 2020; 41(3):191-7. https://doi.org/10.1080/0167482X.2020.1801625.

48. Kolenikov S, Angeles G. The use of discrete data in PCA: theory, simulations, and applications to socioeconomic indices, vol. 20. Chapel Hill: Carolina Population Center, University of North Carolina; 2004. p. $1-59$.

49. Revelle W, Zinbarg RE. Coefficients alpha, beta, omega, and the glb: comments on Sijtsma. Psychometrika. 2009;74(1):145-54. https://doi.org/10. 1007/s11336-008-9102-z.
50. Jardine J, Relph S, Magee LA, et al. Maternity services in the UK during the coronavirus disease 2019 Pandemic: a national survey of modifications to standard care. BJOG. 2020:1-10. https://doi.org/10.1111/1471-0528.16547.

51. Fallon V, Silverio SA, Halford JCG, Harrold JA, Christiansen P. The postpartum specific anxiety scale: confirmatory factor analyses and relationships with birth experience. Paper presented at the 40th anniversary biennial conference of the international Marcé Society for Perinatal Mental Health, lowa City; 2020.

\section{Publisher's Note}

Springer Nature remains neutral with regard to jurisdictional claims in published maps and institutional affiliations.
Ready to submit your research? Choose BMC and benefit from:

- fast, convenient online submission

- thorough peer review by experienced researchers in your field

- rapid publication on acceptance

- support for research data, including large and complex data types

- gold Open Access which fosters wider collaboration and increased citations

- maximum visibility for your research: over $100 \mathrm{M}$ website views per year

At BMC, research is always in progress.

Learn more biomedcentral.com/submissions 